ON THE ORIGIN AND METAIIORPHOSES OF INSECTS*

VII.

ON THE ORIGIN OF INSECTS

"PERSONNE," says Carl Vort, "en Europe au moins, n'ose plus soutenir la Création indépendante et de toutes pieces -des especes," and though this statcment is perhaps not strictly correct, still it is no doubt true, that the Doctrine of Evolution, in some form or
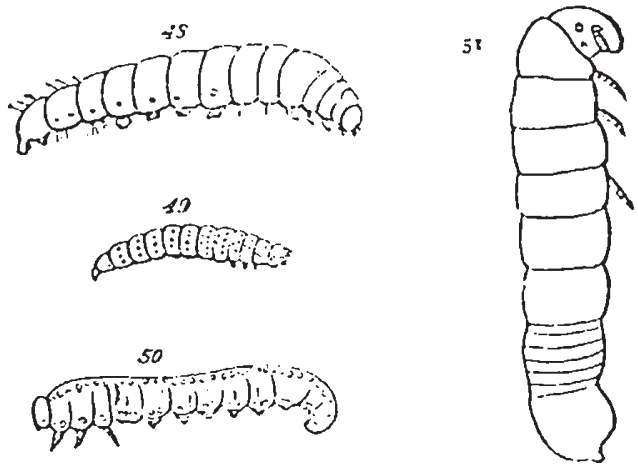

Fic. 49, Larva of Moth (Agrotis suffics.z), afier Packard. 47, Larwa of Beetle (Ha:ticia), after Westwood. 50, Iarva of Sawfy (Cimbex), Brischke and Zaddach Peob ub d. arten. der Blatt und Holzwespen, Fig. 8 51, Lavia of Julus. Newport, Philos. Transaction;, 134 t.

other, is acceptcd by most, if not by all, the greatest naturalists of Europe. Yet it is surprising how much, in spite of all that has been written, Mr. Darwin's views are
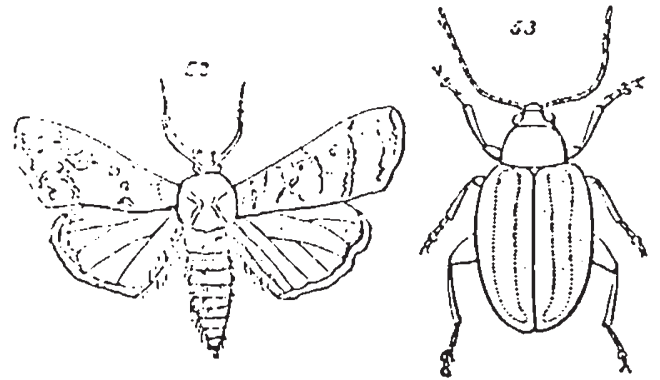

FIG. 52, Agrotis suffusa (after Packard). 53, Haltica (after Westwod).

still misunderstood. Thus Browning, in one of his recent poems, says :-

"That mass man sprang from was a jelly lump Once on a time; he kept an after course

'Through fish and insect, reptile, birl, and beast, Till he attained to be an ape at last,

Or last but one." $\dagger$

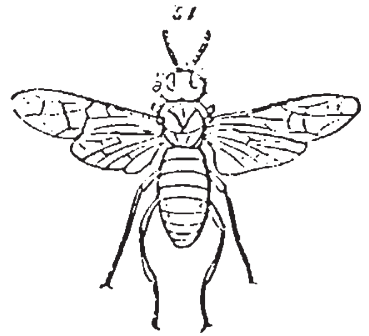

FiG. 54, Cimbex, Brischke and Zaddach, 1.c. T. 2, Fis. 9.

Yet this is a theory which Mr. Darwin would entirely repudiate; which is utterly inconsistent with his vicws.

- Continued from p. 2 to

1 Pricce Hohenstiel Schwangau, p. 63.
Whether fish and insect, reptile, bird, and beast, are derived from one original stock or not, they are certainly not links in one sequence. I do not, however, propose to discuss the question of Natural Selection, but I may obscrve that it is one thing to acknowledge that in Natural Selection, or the survival of the fittest, Mr. Darwin has called attention to a vera causa, has pointed

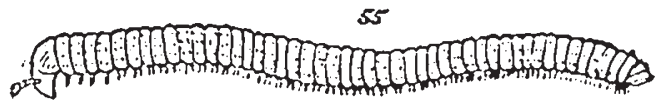

FiG. 55, Julus (after Gervais).

out the true explanation of certain phenomena; but it is quite another thing to maintain; that all animals are descended from one primordial source.

For my own part, I am satisfied that Natural Selection is a true cause, and that whatever may be the final result of our present inquiries - whether animated nature is derived from one ancestral sodrce, or from many-the
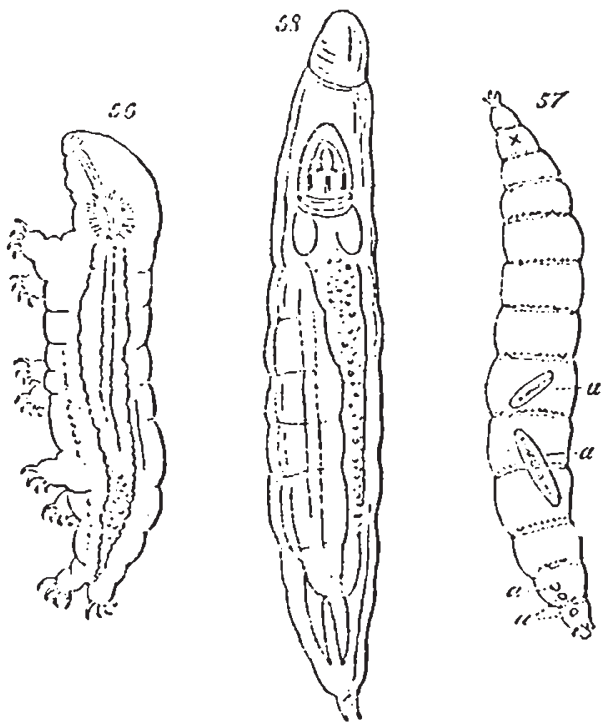

Fic, ${ }_{5}^{6}$, Tardizrade (afier Dujurdin). 57 , I arva of Cecidomyia (after Packard). 53, Lindiz torulosa (after Dujardin).

publication of the Origin of Species will not the less have constituted an epoch in the History of Biology. But, how far the present condition of living beings is due to that cause; how far, on the other hand, the action of Natural Selection has been modified and checked by other natural Iaws-by the unalterability of typas, by atavism, Sc. ; how many types of life originally caine into

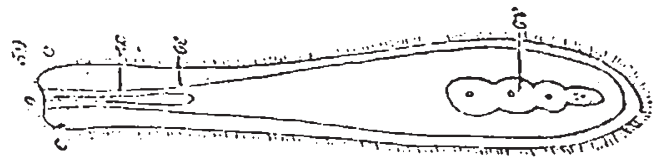

Fic. 59 , Prorhynchus stagnalis.

being; and whether they arose simultaneously or succes. sively, - these and many other similar questions remain unsolved, even if we admit the theory of Natural Sclection. All this has indced been clearly pointed out by Mr. Darwin himself, and would not need repetition but for the careless criticism by which in too many cases the true question has been obscured. Without, however, dis. cussing the argument for and against Mr. Darwin's conclusions, we so often meet with travesties of it like that which I have just quoted, that it may be worth while to con. sider the stages through which some group, say for instance 
that of insects, have probably come to be what they are, assuming them to have developed under natural laws from simpler organisms. The question is one of great difficulty. It is hardly necessary to say that insects cannot have passed through all the lower forms of animal life, and the true line of their development would not at pre. sent 'be agreed upon by all naturalists. In this question embryology and development are perhaps our best guides. The various groups of Crustacea, for instance, greatly as they differ in theur mature condition, are for the most part very similar when they quit the egg. Haeckel, in his "Naturliche Schopfungsoeschichte," gives a diagram which illustrates this very clearly.

In the case of insects, the gradual course of evolution through which the present condition of the group has been probably arrived at, has been discussed by Alr. Darwin, by Fritz Müller, Haeckel, Brauer, myself and others. At first sight the differences are indeed great between the various groups of insects. The stag bectle, the dragon fly, the moth, the bee, the ant, the gnat, the grasshopper - these and other less familiar types seem at first to have little indeed in common. They differ in size,
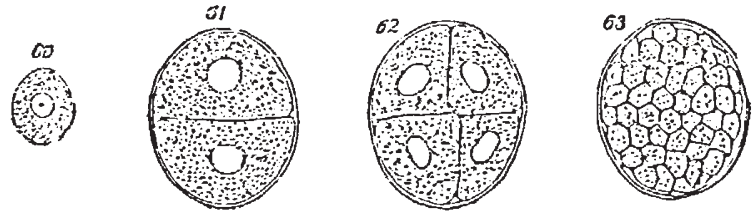

Frc.60, Egg of Tardigrade, Kaufmann, Zcit. f. IVics. Zool. 18jy, Pl. If Tr, Egg of Tardigrade after the yolk has subdivided. 62, Egg

in form, in colour, in habits, and modes of life. Yet the researches of entomologists, following the clue supplied by the illustrious Savigny, have shown, not only that while differing greatly in details, they are constructed on one common plan; but also that other groups, as for instance, Crustacea (Lobsters, Crabs, \&c.) and Arachnida (Spiders and Mites), can be shown to be fundamentally similar. In Pl. 4 I have figured the larva of an Ephemera (Fig. 1), of a Meloe (Fig. 2), of a Dragon Fly (Fig. 3), of a Sitaris (Fig. 4), of a Campodea (Fig. 5), of a Dyticus (Fig. 6), of a Termite (Fig. 7), of a Stylops (Fig. 8), and of a Thrips (Fig. 9). All these lirva possess many characters in common. The mature forms are represented in the corresponding figures of Plate 3 , and it will at once be seen how considerably they differ from one another. The same fact is also illustrated in Figs. $48-55$, where Figs. $48-5$ I represent the larval states of the mature forms represented in Figs. 52-55. Fig. 48 is the larva of a moth, Agrotis suffusa (Fig. 52); Fig. 49 of a beetle, Haltica (Fig. 53); Fig. 50 of a Saw Fly, Cimber (Fig. 54); and Fig. 51 of a Centipede, Fulus (Fig. 55).

Thus then, althojgh it can be demonstrated that perfect insects, however much they dilfer in appearance, are yet reducible to one type, the fact becomes much more evident if we compare the larve. M. Brauer* and It have pointed out that two types of larva, which Packard has proposed to call the Eruciform and Leptiform, run through the principal groups of insects. This is obviously a fact of great importance: as all individual Meloës are derived from a forn resembling Plate 2, Fig. 2 , it is surely no rash hypothesis to suggest that the genus itself may be so.

Firstly, however, let me say a word as to the general Insect type. It may shortly be described as consisting of animals, possessing a head, with mouth-parts, eyes, and antenna ; a thorax made up of three segments, each with a pair of legs; and a many-segmented abdomen with anal appendages. Into the internal anatomy I will not now enter. It will be seen that Plate 4 , Fig. 4, representing the larva of a small beetle named Sitaris, answers very well to this description. Many other Beetles are developed from larva closely resembling those of Melö̈ (Plate 4, Fig. 2), and Sitaris (Plate 4, Fig. 4); in fact-except those species the larva of which, as, for instance of the IVeevils (Plate 2, Fig. 6), are internal feeders, and do not require legs-we may say that the Coleoptera generally are derived from larva of this type.

I will now pass to a second order, the Neuroptera. Plate 4, Fig. I, represents the larva of Chloëon, a species the metamorphoses of which 1 described some years ago in the Linnean Transactions, and it is obvious that in essential points it closely resembles the form which I have just described.

The Orthoptera, again, the order to which Grasshoppers, Crickets, Locusts, \&c. belong, commence life in a similar condition, and the same may also be said of the Trichoptera.

From the difference in external form, and especially the large comparative size of the abdomen, the larvae of Lepidoptera (Fir. 48), and of certain Hymenoptera, for instance, of Sirex (Fig. 1.4) and of the Saw Flies (Fig. 50), have generally been classed with the maggots of Flies, Bees, IVeevils, \&c., rather than with the more active form of larva just adverted to. This seems to me, as I have already pointed out, $\dagger$ to be a mistake. If we look, for instance, at the larva of Tenthredo we sce the three thoracic segments well marked, and the three pairs of legs. The abdominal prolegs, indeed, give the Iarva a very different appearance to those of the preceding type, but in some respects remove them still further from the apod, vermiform, larva. The larve of other species belonging to this group, for instance of Lyda, have no abdominal prolegs, and well developed though short antenne. The caterpillar type differs then in its general appearance owing to its greater clumsiness, but still essentially agrees with that already described.

No Dipterous larva, so far as I know, belongs truly to this type; in fact, the early stages of the pupa in the Diptera seem in some respects to correspond to the larvec of other Insect orders. The Development of the Diptera is, however, as IVeissman $\ddagger$ has shown, very abnormal in other respects.

Thus then we find in many of the principal groups of insects that, greatly as they differ from one another in their mature condition, when they leave the $\mathrm{egg}$ they consist of a head; a three-segmented thorax, with three pairs of legs; and a many-jointed abdomen, often with anal appendages. Now is there any mature animal which answers to this description? We need not have been surprised if this type, through which it would appear that insects must have passed so many ages since (for winged Neuroptera have been found in the carboniferous strata) had long ago become extinct. Yet it is not so. The interesting genus Campodea (Pl. 3, Fig. 5) still lives; it inhabits damp earth, and closely resembles the larva of Chloëon (PI. 2, Fig. 1), constituting, indeed, a type which, as shown in Pl. 4, occurs in many orders of insects. It is true that the mouth parts of Campodea do not resemble either the strongly mandibulate form which prevails among the larve of Coleoptera, Orthoptera, Neuroptera, Hymenoptera, and Lepidoptera; or the suctorial type of the Homoptera and Heteroptera. It is, however, not the less interesting or significant on that account, since, as I have elsewhere endeavoured to point out, its mouth parts are intermediate $\$$ between the mandibulate and haustillate types; a fact which seems to me highly significant.

It seems to me, then, that there are good grounds for

* Linnean Transactions, 1866, vol. xxv.

1 Siebold and Kolliker's Zeits. f. Wiss. Zool, , 1564 .
Linnaan Joumal, v, xi. 
considering that the various types of insects are descended from ancestors more or less resembling the genus Campodea, with a body divided into head, thorax, and abdomen; the head provided with mouth-parts, eyes, and one pair of antennx, the thorax with three pairs of legs, and the abdomen, in all probability, with caudal appendages.

If these views are correct, the genus Campodea must be regarded as a form of remarkable interest, since it is the living representative of a primaval type from which not only the Collembola and Thysanura, but the other great orders of insects have derived their origin.

This ancient type may possibly have been derived from a less highly devcloped one, resembling the modern Tardigrades, a (Fig. 56) smaller and much less highly organised being than Campodea, which has been successively placed among the Acari and the Rotatora. It possesses two eyes, three anterior pairs of legs, and onc at the posterior end of the body, giving it a curious resemblance to some Lepidopterous larva.

These legs, however, as it will be seen, are reduced to mere projections. But for them, the Tardigrada would closely resemble the vermiform larva so common among insects. Among the Coleoptera, for instance, the vermiform type occurs in the weevils; among Hymenoptera in the Bees and Ants; among Diptera it is general. Among Trichoptera the larva early acquires the three pairs of legs, but as Zaddach has shown,* there is a stage, though it is quickly passed through, in which the divisions of the body are indicated, but no trace of legs is yet present. Indeed, there appear to be reasons for considering that while among Crustacea the appendages appear before the segments, in Insects the segments precede the appendages, although this stage of development is very transitory, and apparently, in some cases, altogether suppressed. I say " apparently," because I am not yet satisfied that it will not eventually be found to occur in all cases. Zaddach, in his careful observations of the embryology of Phryganea, only once found a specimen in this stage, which also, according to the researches of Huxley, $t$ seems to be little more than indicated in Aphis. It is therefore possible that in other cases, when no such stage has been observed, it is not really absent, but, from its transitoriness, has hitherto escaped attention.

Fritz Muller has expressed the opinion $¥$ that this vermiform type is of comparatively recent origin; he says, "the ancient insects approached more nearly to the existing Orthoptera, and perhaps to the wingless Blattidx, ihan to any other order, and the complete metamorphosis of the Beetles, Lepidotera, \&c. is of later origin." "There were," he adds, "perfect insects before larva and pupx." This opinion has been adopted by Mr. Packard $\$$. in his "Embryological Studies on Hexapodous Insects."

M. Brauer || also considers that the vermiform larva is a more recent type than the Hexapod form, and is to be regarded not as a developmental form, but as an adaptational modification of the earlier active hexapod type. In proof of this he quotes the case of Sitaris.

Considering, however, the peculiar habits of this genus, to which I have already referred, and that the vermiform type is altogether lower in organisation and less ${ }^{\circ}$ differentiated than the Campodea form, I cannot but regard this case as cxceptional; as one in which the development has been, so to say, "falsified" by the struggle for existence, to use an expression of Fritz Müller's, and which therefore does not truly indicate the successive stages of evolution. On the contrary, the facts seem to me to point to the conclusion that, though the grublike larvi of Coleoptera, and

* Unters. ub. die Entwick. und der Bau der Gliederthiere, p. 73

+ Linnean Transactions, v. xxii.

1 Facts for Darwin, trans. by Dallas, p. ris.

$\$$ Mem. Peabody Academy of Science, v. I. No. 3

\#Wien. Zool. Bott. Geselis. ISég, P. 3 ro. some other insects, owe their present form mainly to the influence of external circumstances, and partially also to atavism, still the Campodea type is itself derived from earlier vermiform ancestors. Nicolas Wagner has shown in the case of a small gnat, allied to Cecidomyia, that even now, in some instances, the vermiform larva retain the power of reproduction. Such a larva (as, for instance, Fig. 57) very closely resembles some of the Rotatoria, such, for instance, as Albertia or Notommata; these differ generally in possessing vibratile cilia. There is, however, one genus-Lindia (Fig. 58) -in which these cilia are altogether absent, and which, though resembling Macrobiotus in many respects, differs from that genus in being entirely destitute of legs. I have never met with it myself, but it is described by Dujardin, who found it in a ditch near Paris, as oblong, vermiform, divided into rings, and terminating posteriorly in two short conical appendages. The jaws are not unlike those of the larva of Flies, and indeed many naturalists meeting with such a creature would, I am sure, regard it as a small Dipterous larva ; yet Dujardin figures a specimen containing an egg, and seems to have no doubt that it is a mature form.*

(To be continuted.)

JoIn LUBROCk

\section{AMERICAN SCIENTIFIC EXPEDITIONS†}

$T H E$ present year will be pre-eminently characterised in the history of the United States by the number of scientific expeditions, thoroughly equipped in every respect, and fitted out for exploration in various regions of the great IVest; and although most of them have been already referred to in our columns, it may be well to recapitulate them in geographical order. The most northerly is the International Northern Boundary Commission, which is intended to survey the line of the fortyninth parallel, from the Lake of the. IVoods to the crest of the Rocky. Mountains. The survey of the castern section of the northern boundary of the United States was com. pleted many years ago. by Colonel J. D. Graham and others, and that of the western section, from the Pacific coast to the Rocky Mlountains, was brought to a close in 1860. The middle section, as was the western, is in charge of Archibald Campbell, Esq., of Washington, as commissioner, with Major Twining as chief engineer officer on the part of the United States. Dr. Elliott Coues, of the army, the well-known naturalist, accompanies the expedition in that capacity, and the work ivill be done in connection with a large party, equally well equipped, detailed by the British Government.

The labour of this Commission was begun in 1872 , consisting in the examination of the line from the Lake of Voods to Pembina, this village being the starting-point for the present year.

The next expedition is that along the line of the Northern Pacific Railway, and will consist of a body of about 2,000 troops, under the immediatc command of Colonel D. N. Stanley. This will concentrate at Fort Abraham Lincoln, on the Missouri, now representing the western terminus of the Northern Pacific Railway, and its route will be westward toward and across the Yellow Stone River. This large force is intended to keep the Indians in check, and prevent any interferences on their part with the location and construction parties of the railway. In view of the fact that this expedition passes through a rich but little-known country, abounding in objects of natural history and zoology, the president of the National Academy of Sciences memorialised the Secretary of War in reference to the appointment of a

* See also the descriptions given by Dujardin (Ann. des Sci. Nat. I851, v. xv.) and Claparide (Anat. and Entwickl der Wirbel'osen Thiere) of the interesting genus Echinoderes, which these two eminent natu $a$ 'is's

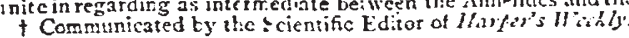

